ACTA AGROBOTANICA

Vol. 62 (2): 165-172

2009

\title{
RESPONSE TO CHILLING IN CUCUMBER (Cucumis sativus L.) PLANTS TREATED WITH TRIACONTANOL AND ASAHI SL
}

\author{
Edward Borowski
}

\author{
Department of Plant Physiology, University of Life Sciences in Lublin, Akademicka 15, 20-950 Lublin, Poland \\ e-mail: fizjologia.roslin@up.lublin.pl
}

Received: 16.06.2009

\section{Abstract}

In pot experiments on cucumber cv. Śremski $F_{1}$, the effect of short-term chilling on plants earlier treated with triacontanol (TRIA) and Asahi SL was investigated. These plants were grown in a phytotron at an air temperature of $27 / 22^{\circ} \mathrm{C}$ (day/night), using fluorescent light with far flux density of 220 $\mu \mathrm{mol} \times \mathrm{m}^{-2} \times \mathrm{s}^{-1}$, with a photoperiod $16 / 8$. At the 4 th true leaf stage, the respective experimental series were sprayed with: 1) $\mathrm{H}_{2} \mathrm{O}$ - control, 2) TRIA $\left.0.01,3\right)$ TRIA $\left.0.1,4\right)$ TRIA $1.0 \mathrm{mg} \times$ $\left.\mathrm{dm}^{-3}, 5\right)$ Asahi SL 0.2, 6) Asahi SL 0.3\%. After 24 hours one half of the plants from each experimental series was treated for a period of 3 days at a temperature of $12 / 6^{\circ} \mathrm{C}$, with all the other growth conditions unchanged. The obtained results have shown that short-term chilling stress caused a significant increase in electrolyte leakage, free proline content and in the activity of guaiacol peroxidase in leaves, but a decrease in chlorophyll $a+b$ content, stomatal conductance, transpiration, photosynthesis, leaf area and in the activity of catalase in leaves. The application of TRIA or ASAHI SL on leaves in the pre-stress period reduced the values of the traits which had been increased as a result of chilling and increased those which had reduced. Generally, TRIA was most effective at a concentration of $0.1 \mathrm{mg} \times \mathrm{dm}^{-3}$, and Asahi SL at a concentration of $0.3 \%$.

Key words: stress, biostimulators, electrolytes, proline, catalase, peroxidase, photosynthetic pigments, gas exchange

\section{INTRODUCTION}

Cucumber is a vegetable which is commonly grown in the conditions of Poland in field, in greenhouses and plastic tunnels. The optimal temperature for plant growth is $20-25^{\circ} \mathrm{C}$. It is sensitive to ground frost and to persistent temperatures below $10^{\circ} \mathrm{C}$, called chilling temperatures. The magnitude of chilling injury depends on air temperature, time of exposition, plant growth stage and it usually manifests itself after plants are transferred to a higher temperature. Chill- ing temperatures in leaves of thermophilic plants cause the degradation of membrane lipids and decreased integrity of cell membranes (De Kok and Kuiper, 1977; Chen and Lin, 1993), changes in the composition of photosynthetic pigments ( $\mathrm{H}$ a ld i man $n$, 1998), decreased leaf stomatal conductance (S t a r c k et al. 2000) and decreased photosynthesis (Fo y e r et al. 1994a; H a l d i m a n n, 1998; S t a r c k et al. 2000; J u n - S u n g s o o et al.2001). The reduction in $\mathrm{CO}_{2}$ fixation rate, induced by low temperature stress, leads to excessive accumulation of reactive oxygen forms (Robinson, 1988; Ôquist and Huner, 1993) and increased activity of antioxidant enzymes ( $\mathrm{G} \mathrm{ra}$ ham and Patterson, 1982; El-Saht, 1998; Dong Hee Lee and Chin Bum Lee, 2000; Feng-Zhaozhong et al. 2003). Chilling stress also causes increased accumulation of free proline in plant leaves (A it-Barka and Audran, 1997; Hare and Cress, 1997; Chen and Li, 2002).

The most frequent method used to increase plant tolerance to chilling stress is plant hardening which can be done before field planting, whereas during the growth of plants biostimulators can be used for this purpose.

Triacontanol (TRIA) is a primary alcohol $\left[\mathrm{CH}_{3}\left(\mathrm{CH}_{2}\right)_{28} \mathrm{CH}_{2} \mathrm{OH}\right]$ naturally occurring in plant waxes. Existing research has shown that TRIA application stimulates dry matter accumulation in leaves (B o r o w s ki, 1992), increases the content of photosynthetic pigments ( $\mathrm{K} \mathrm{u} \mathrm{m}$ a r a velu et al. 2000) and the $\mathrm{CO}_{2}$ assimilation rate $(\mathrm{M}$ is tra and $\mathrm{Sriv}$ a stava, 1991; Muthuchelian et al. 1995; I w an ow and A ngelow, 1997; B la mow ski et al. 1998).

Asahi SL (A tonik) contains natural substances found in plants, such as 5-nitroguaiacolate as well as ortho- and para-nitrophenolate. Its application in plants stimulates their growth $(\mathrm{Dj}$ a naguiraman et al. 2005; Górnik and Grzesik, 2005; 
Gawrońska et al. 2008), increases the content of photosynthetic pigments (Mikos-Bielak and Michałek, 1999; Gawrońska et al. 2008), facilitates transpiration and photosynthesis processes (G awrońska et al. 2008; Wróbel and Wo źniak 2008), as well as enhances the activity of antioxidant enzymes ( $\mathrm{Dj}$ a n a g i r a m a n et al. 2005; G a w r o ń s k a et al. 2008) and plant tolerance to chilling stress ( $\mathrm{G}$ ó r n i k et al. 2007).

Existing research on the application of TRIA and Asahi SL gives the basis for the supposition that both biostimulators may have a beneficial influence on plants subjected to chilling stress. Therefore, the aim of the present study was to determine the effect of chilling stress on cucumber (Cucumis sativus L.) plants earlier treated with different concentrations of TRIA and Asahi SL.

\section{MATERIALS AND METHODS}

The experiments were conducted in a phytotron of the University of Life Sciences in Lublin in the period 16 May - 9 June and 18 June - 16 July 2008. Seeds of cucumber cv. Śremski $F_{1}$ were sown into 84 pots with a diameter of $17 \mathrm{~cm}$, filled with growing medium manufactured by the company Hollas from sieved and milled sphagnum peat with the addition of Hydro fertilizer, chalk and fine washed quartz sand. After emergence, unnecessary seedlings were removed, leaving 2 plants per pot. Until the 4th true leaf stage, the plants were grown in a room with an air temperature of $27 / 22^{\circ} \mathrm{C}$ (day/night), relative humidity of approx. $60 \%$, using fluorescent light with far flux density of $220 \mu \mathrm{mol} \times \mathrm{m}^{-2} \times \mathrm{s}^{-1}$, with a photoperiod $16 / 8$ (day/ night). The moisture content of the growing medium in the pots was maintained at a level of $70 \%$ (field water capacity - FWC), using "weight-based" watering. At the 4th true leaf stage, i.e., after 3 weeks of growth, the plants were divided into 6 experimental series (with 14 pots in each) differing in the type and concentration of the biostimulator applied: 1) control $-\mathrm{H}_{2} \mathrm{O}$; 2) triacontanol (TRIA) - 0.01 ; 3) TRIA - 0.1 ; 4) TRIA - 1.0 $\mathrm{mg} \times \mathrm{dm}^{-3}$; 5) Asahi SL - 0.2;6) Asahi SL - 0.3\%. The biostimulators were administered by spraying the plants; the spraying was done in morning hours using a hand sprayer, applying ca. $5 \mathrm{~cm}^{3}$ of the solution per pot. After 24 hours one half of the plants from each experimental series ( 7 pots) remained in the same conditions, whereas the other part (7 pots) was transferred to another phytotron and subjected to a temperature of $12 / 6^{\circ} \mathrm{C}$ (day/night) with relative air humidity of approx. $95 \%$.

Immediately after the three-day period of the action of chilling stress, the following parameters were determined in leaves of the plants treated and not treated with chilling: electrolyte leakage (EL) in accordance with the methodology presented in the paper of Markowski and Skrudlik (1995), free proline content according to B ates et al. (1973), chlorophyll content according to A r n o n (1949) and carotenoid content according to B r i t t o n (1985). Immediately after chilling stress, samples were also collected to determine the activity of catalase (CAT) and guaiacol peroxidase (POD). The plant material was homogenised in a homogeniser with the addition of 5 $\mathrm{cm}^{3}$ of phosphate buffer, with a $\mathrm{pH}$ of 7.8 in the case of catalase and a $\mathrm{pH}$ of 7.0 in the case of guaiacol peroxidase, at a temperature of $4^{\circ} \mathrm{C}$. The homogenate was poured into test tubes and centrifuged at $4^{\circ} \mathrm{C}$ at a speed of $10000 \mathrm{~g}$ for $15 \mathrm{~min}$. (catalase) or $10 \mathrm{~min}$. (guaiacol peroxidase). In the solution obtained, extinction readings were made using the spectrophotometric method at a wavelength of $240 \mathrm{~nm}$ for catalase (A e b i , 1984) and at a wavelength of $480 \mathrm{~nm}$ for guaiacol peroxidase (M a łoleps za et al. 1994). The activity of the enzymes was expressed in $\mathrm{U} \times \mathrm{g}^{-1}$ f.m., which means, in the case of catalase, the decomposition of $1 \mu \mathrm{mol} \mathrm{H}_{2} \mathrm{O}_{2}$ $\times \min ^{-1} \times \mathrm{g}^{-}$f.m., and in the case of guaiacol peroxidase $\Delta \mathrm{E} \times \min ^{-1} \times \mathrm{g}^{-1}$ f.m. The abovementioned assays were performed in 4 replicates.

After collecting leaf samples from the chilling-treated cucumber plants, the plants were returned to the previous conditions of $27 / 22^{\circ} \mathrm{C}$ in which, after 24-hour adaptation, measurements were made of leaf stomatal conductance, transpiration and photosynthesis rate. Determinations were made in 8 replicates using a LCA-4 leaf microclimate control system. During recording, the temperature in the measurement chamber was approx. $30^{\circ} \mathrm{C}$, and far flux density 200 $\mu \mathrm{mol} \times \mathrm{m}^{-2} \times \mathrm{s}^{-1}$. In the same leaves, measurements were also made of minimum fluorescence $\left(\mathrm{F}_{\mathrm{o}}\right)$, maximum fluorescence $\left(\mathrm{F}_{\mathrm{m}}\right)$ and maximum quantum yield of chlorophyll $\left(\mathrm{F}_{\mathrm{v}} / \mathrm{F}_{\mathrm{m}}\right)$; however, due to the absence of significant differences these data are not presented in the present paper. After making the abovementioned measurements, total leaf area in the cucumber plants was also determined using a planimeter in 4 replicates. The data presented in this paper are the means from two experiments conducted; they were subjected to analysis of variance for double cross-classification. The significance of differences between the means was determined using Tukey's confidence half-interval, denoted in the present paper as LSD.

\section{RESULTS AND DISCUSSION}

The results presented in Tab. 1 show that the chilling-treated plants demonstrated a $68.2 \%$ higher electrolyte leakage from leaf cells than the plants not subjected to stress. Pre-stress spraying of the plants with 
triacontanol evidently reduced the value of EL both in the untreated plants and plants treated with chilling. TRIA was most effective at a concentration of $0.1 \mathrm{mg}$ $\times \mathrm{dm}^{-3}$, which reduced electrolyte leakage by $42.5 \%$ in the first case, and in the other case by $27.0 \%$ relative to the control treatment. Triacontanol at a concentration of $1.0 \mathrm{mg} \times \mathrm{dm}^{-3}$ was least effective; in this case, analogous data for the untreated and chilling-treated plants were $13.9 \%$ and $5.6 \%$, respectively. The value of the trait in question in the Asahi SL-treated plants was also at a similar level, since the application of the biostimulator in the plants not subjected to chilling stress reduced electrolyte leakage for both concentrations by $13.9 \%$, on the average, and in the chilled plants by $21.4 \%$. It seems that the partial dysfunction of cell membranes and their decreased integrity under the stress conditions are induced by the degradation of membrane lipids, which is indicated by the studies of De Kok and Kupier (1997) as well as of Chen and Lin (1993).

It was found that the beneficial influence, under the chilling stress conditions, of TRIA and Asahi SL on cells was multi-directional, being related, inter alia, to the effect of free proline on synthesis. The obtained results showed that the control plants subjected to chilling contained, compared to the plants not treated with chilling stress, over 5 times more free proline in their leaves, which is also confirmed by other authors (A it-Barka and Audran, 1997; Hare and Cress, 1997; Chen and Li, 2002). The application of triacontanol increased the amino acid content in the cucumber leaves not treated with chilling by 6.3 , on the average, relative to the control treatment, and the application of Asahi SL by $3.4 \mu \mathrm{g} \times \mathrm{g}^{-1}$ f.m., on the average. The chilling-treated plants, and earlier sprayed with TRIA or Asahi SL before the application of stress, contained less free proline by 27.7 and 17.9 $\mu \mathrm{g} \times \mathrm{g}^{-1}$ f.m., respectively, relative to the control treatment. It indicates that both biostimulators used offer partial protection against the effects of stress, hence the decrease in free proline which performs the role of a protective substance also under stress conditions.

Antioxidant enzymes, such as e.g. catalase and guaiacol peroxidase, also perform a similar role as proline under stress conditions. The results obtained in the present experiments demonstrated that both in the control plants and biostimulator-treated plants chilling stress applied significantly reduced the activity of catalase by $17.0 \%$, on the average, relative to the plants not subjected to chilling. But the application of triacontanol, both in the untreated and chilling-treated plants, significantly increased the activity of the enzyme by, respectively, $72.7 \%$ and $71.5 \%$, on the average, compared to the control plants. In this respect, TRIA was most effective at a concentration of $0.1 \mathrm{mg}$ $\times \mathrm{dm}^{-3}$, and least effective at a concentration of $1.0 \mathrm{mg} \times$ $\mathrm{dm}^{-3}$. The influence of Asahi SL was analogous; in the plants not subjected to stress it increased the average activity of catalase by $57.5 \%$ and in the stress-treated plants by $64.5 \%$, but the solution was more effective at a concentration of $0.3 \%$ (Tab. 2). However, the effect of chilling stress on the activity of guaiacol peroxidase in cucumber leaves was different, since in the control plants short-term chilling increased the activity of the enzyme more than twice, in the plants in which TRIA had been applied earlier more than 17 times, on the average, and in the plants with Asahi SL application -8.5 times. But the earlier application of the biostimulators, in particular TRIA, in the plants not treated with chilling decreased the activity of peroxidase, whereas in the chilling-treated plants it clearly increased this activity, nearly three times, on the average, under the influence of triacontanol and four times under the influence of Asahi SL (Tab. 2). D ong He e Lee and Chin B um Lee (2000) as well as Graham and Patters on (1982) also note a significant increase in the activity of guaiacol peroxidase and a decrease in the activity of catalase under the influence of chilling stress, substantiating it with very low affinity of catalase for $\mathrm{H}_{2} \mathrm{O}_{2}$. But an increased activity of both enzymes under the influence of Asahi SL have been also observed by Djanaguiraman et al. (2005) and Gaw rońs ka et al. (2008), whereas Górnik et al. (2007) have observed increased tolerance to chilling under these conditions.

As indicated by the results contained in Tab. 3 , chilling stress also affected significantly the content of chlorophyll $a+b$ in cucumber leaves, whereas it had no effect on the carotenoid content. Irrespective of the type and concentration of the biostimulators used, the chilling-treated plants contained in their leaves, on the average, $15 \%$ less chlorophyll than the plants not subjected to chilling stress, which is also confirmed by Haldimann (1998). The application of the biostimulators in the pre-stress period had a beneficial effect on the content of both chlorophyll $a+b$ and carotenoids in the cucumber leaves treated and not treated with chilling. The plants sprayed with TRIA contained, on the average, $11.9 \%$ more chlorophyll $\mathrm{a}+\mathrm{b}$ relative to the control plants, and $7.9 \%$ in the case of those sprayed with Asahi SL, whereas the respective data for carotenoids were $19.0 \%$ and $26.2 \%$. Triacontanol administered at a concentration of $0.1 \mathrm{mg}$ $\times \mathrm{dm}^{-3}$, and Asahi SL at a concentration of $0.3 \%$, had by far the most beneficial effect on the value of the trait in question. Other researchers also confirm the stimulating effect of TRIA ( $\mathrm{K} \mathrm{u} \mathrm{m}$ arave $\mathrm{lu}$ et al. 2000) and Asahi SL (Mikos-Bielak and Michałek, 1999; Gawrońska et al. 2008) on the content of photosynthetic pigments in plants. 
Table 1

Effect of chilling on electrolyte leakage (EL) and proline content in cucumber leaves treated with triacontanol (TRIA) and Asahi SL.

\begin{tabular}{|c|c|c|c|c|c|c|c|}
\hline \multirow[b]{2}{*}{ Biostimulator (A) } & \multirow[b]{2}{*}{ Concentration } & \multicolumn{2}{|c|}{ Growth conditions (B) } & \multirow{2}{*}{$\begin{array}{l}\text { Mean } \\
\text { for A }\end{array}$} & \multicolumn{2}{|c|}{ Growth conditions (B) } & \multirow{2}{*}{$\begin{array}{l}\text { Mean } \\
\text { for A }\end{array}$} \\
\hline & & $\begin{array}{l}\text { without } \\
\text { chilling }\end{array}$ & $\begin{array}{c}\text { with } \\
\text { chilling }\end{array}$ & & $\begin{array}{l}\text { without } \\
\text { chilling }\end{array}$ & $\begin{array}{c}\text { with } \\
\text { chilling }\end{array}$ & \\
\hline & \multicolumn{4}{|c|}{$\mathrm{EL}(\%)$} & \multicolumn{3}{|c|}{ proline $\left(\mu \times \mathrm{g}^{-1}\right.$ f.m. $)$} \\
\hline Control & $\mathrm{H}_{2} \mathrm{O}$ & 24.5 & 41.2 & 32.8 & 16.7 & 88.2 & 52.4 \\
\hline \multirow{3}{*}{$\begin{array}{l}\text { TRIA } \\
\left(\mathrm{mg} \times \mathrm{dm}^{-3}\right)\end{array}$} & 0.01 & 15.1 & 36.5 & 25.8 & 16.6 & 63.4 & 40.0 \\
\hline & 0.1 & 14.1 & 30.1 & 22.5 & 23.4 & 64.2 & 43.8 \\
\hline & 1.0 & 21.1 & 38.9 & 30.0 & 28.9 & 53.9 & 41.4 \\
\hline \multirow{2}{*}{$\begin{array}{l}\text { Asahi SL } \\
(\%)\end{array}$} & 0.2 & 19.5 & 34.2 & 26.8 & 19.7 & 71.6 & 45.6 \\
\hline & 0.3 & 22.7 & 30.7 & 26.7 & 20.6 & 69.0 & 44.8 \\
\hline Mean for B & & 19.5 & 35.3 & & 21.0 & 68.4 & \\
\hline LSD for A & & & 5.8 & & & 6.7 & \\
\hline LSD for B & & & 2.6 & & & 2.6 & \\
\hline LSD for $\mathrm{AxB}$ & & & n.s. & & & 11.1 & \\
\hline
\end{tabular}

Table 2

Effect of chilling on catalase and guaiacol peroxidase activities in cucumber leaves treated with triacontanol (TRIA) and Asahi SL.

\begin{tabular}{|c|c|c|c|c|c|c|c|}
\hline \multirow{2}{*}{ Biostimulator (A) } & \multirow{2}{*}{ Concentration } & \multicolumn{2}{|c|}{ Growth conditions (B) } & \multirow{2}{*}{$\begin{array}{l}\text { Mean } \\
\text { for A }\end{array}$} & \multicolumn{2}{|c|}{ Growth conditions (B) } & \multirow{2}{*}{$\begin{array}{l}\text { Mean } \\
\text { for A }\end{array}$} \\
\hline & & $\begin{array}{l}\text { without } \\
\text { chilling }\end{array}$ & $\begin{array}{c}\text { with } \\
\text { chilling }\end{array}$ & & $\begin{array}{l}\text { without } \\
\text { chilling }\end{array}$ & $\begin{array}{c}\text { with } \\
\text { chilling }\end{array}$ & \\
\hline & \multicolumn{3}{|c|}{ catalase $\left(\mathrm{U} \times \mathrm{g}^{-1}\right.$ f.m. $)$} & & \multicolumn{3}{|c|}{ peroxidase $\left(\mathrm{U} \times \mathrm{g}^{-1} \mathrm{f} . \mathrm{m}.\right)$} \\
\hline Control & $\mathrm{H}_{2} \mathrm{O}$ & 86.2 & 70.8 & 78.5 & 38.1 & 86.5 & 62.3 \\
\hline TRIA & 0.01 & 149.5 & 105.4 & 127.4 & 13.0 & 216.6 & 114.8 \\
\hline \multirow[t]{2}{*}{$\left(\mathrm{mg} \times \mathrm{dm}^{-3}\right)$} & 0.1 & 175.9 & 159.7 & 167.8 & 10.8 & 215.8 & 113.3 \\
\hline & 1.0 & 121.4 & 99.0 & 110.2 & 18.7 & 317.7 & 168.2 \\
\hline Asahi SL & 0.2 & 129.0 & 105.4 & 117.2 & 50.7 & 361.1 & 205.9 \\
\hline$(\%)$ & 0.3 & 142.7 & 127.7 & 135.2 & 32.8 & 347.3 & 190.0 \\
\hline Mean for B & & 134.1 & 111.3 & & 27.3 & 257.5 & \\
\hline LSD for A & & & 18.6 & & & 90.8 & \\
\hline LSD for $B$ & & & 7.2 & & & 45.5 & \\
\hline LSD for $\mathrm{AxB}$ & & & n.s. & & & 194.7 & \\
\hline
\end{tabular}


Table 3

Effect of chilling on chlorophyll $\mathrm{a}+\mathrm{b}$ and carotenoid content in cucumber leaves treated with triacontanol (TRIA) and Asahi SL.

\begin{tabular}{|c|c|c|c|c|c|c|c|}
\hline \multirow{2}{*}{ Biostimulator (A) } & \multirow{2}{*}{ Concentration } & \multicolumn{2}{|c|}{ Growth conditions (B) } & \multirow{2}{*}{$\begin{array}{l}\text { Mean } \\
\text { for A }\end{array}$} & \multicolumn{2}{|c|}{ Growth conditions (B) } & \multirow{2}{*}{$\begin{array}{l}\text { Mean } \\
\text { for A }\end{array}$} \\
\hline & & $\begin{array}{l}\text { without } \\
\text { chilling }\end{array}$ & $\begin{array}{c}\text { with } \\
\text { chilling }\end{array}$ & & $\begin{array}{l}\text { without } \\
\text { chilling }\end{array}$ & $\begin{array}{c}\text { with } \\
\text { chilling }\end{array}$ & \\
\hline & \multicolumn{4}{|c|}{ chlorophyll a+b (mg $\times \mathrm{g}^{-1}$ f.m.) } & \multicolumn{3}{|c|}{ carotenoids (mg × $\mathrm{g}^{-1}$ f.m.) } \\
\hline Control & $\mathrm{H}_{2} \mathrm{O}$ & 1.87 & 1.65 & 1.76 & 0.19 & 0.24 & 0.21 \\
\hline & 0.01 & 1.91 & 1.81 & 1.86 & 0.20 & 0.25 & 0.22 \\
\hline \multirow{2}{*}{$\left(\mathrm{mg} \times \mathrm{dm}^{-3}\right)$} & 0.1 & 2.37 & 1.84 & 2.10 & 0.27 & 0.26 & 0.26 \\
\hline & 1.0 & 2.20 & 1.74 & 1.97 & 0.28 & 0.24 & 0.26 \\
\hline Asahi SL & 0.2 & 1.98 & 1.72 & 1.85 & 0.26 & 0.26 & 0.26 \\
\hline$(\%)$ & 0.3 & 2.11 & 1.79 & 1.95 & 0.25 & 0.29 & 0.27 \\
\hline Mean for B & & 2.07 & 1.76 & & 0.24 & 0.26 & \\
\hline LSD for A & & & 0.11 & & & 0.03 & \\
\hline LSD for B & & & 0.04 & & & 0.01 & \\
\hline LSD for $\mathrm{AxB}$ & & & 0.19 & & & 0.04 & \\
\hline
\end{tabular}

Table 4

Effect of chilling on stomatal conductance and transpiration rate of cucumber leaves treated with triacontanol

(TRIA) and Asahi SL.

\begin{tabular}{|c|c|c|c|c|c|c|c|}
\hline \multirow{2}{*}{ Biostimulator (A) } & \multirow{2}{*}{ Concentration } & \multicolumn{2}{|c|}{ Growth conditions (B) } & \multirow{2}{*}{$\begin{array}{l}\text { Mean } \\
\text { for A }\end{array}$} & \multicolumn{2}{|c|}{ Growth conditions (B) } & \multirow{2}{*}{$\begin{array}{l}\text { Mean } \\
\text { for A }\end{array}$} \\
\hline & & $\begin{array}{l}\text { without } \\
\text { chilling }\end{array}$ & $\begin{array}{l}\text { with } \\
\text { chilling }\end{array}$ & & $\begin{array}{l}\text { without } \\
\text { chilling }\end{array}$ & $\begin{array}{c}\text { with } \\
\text { chilling }\end{array}$ & \\
\hline & \multicolumn{4}{|c|}{ conductance $\left(\mathrm{mol} \times \mathrm{m}^{-2} \times \mathrm{s}^{-1}\right)$} & \multicolumn{3}{|c|}{ transpiration $\left(\mathrm{mmol} \times \mathrm{m}^{-2} \times \mathrm{s}^{-1}\right)$} \\
\hline Control & $\mathrm{H}_{2} \mathrm{O}$ & 0.15 & 0.07 & 0.11 & 2.15 & 1.10 & 1.62 \\
\hline & 0.01 & 0.18 & 0.09 & 0.13 & 2.32 & 1.24 & 1.78 \\
\hline \multirow{2}{*}{$\left(\mathrm{mg} \times \mathrm{dm}^{-3}\right)$} & 0.1 & 0.20 & 0.12 & 0.16 & 2.47 & 1.35 & 1.91 \\
\hline & 1.0 & 0.18 & 0.08 & 0.13 & 2.24 & 1.15 & 1.69 \\
\hline \multirow{2}{*}{$\begin{array}{l}\text { Asahi SL } \\
(\%)\end{array}$} & 0.2 & 0.21 & 0.12 & 0.16 & 2.45 & 1.40 & 1.92 \\
\hline & 0.3 & 0.22 & 0.12 & 0.17 & 2.52 & 1.47 & 1.99 \\
\hline Mean for B & & 0.19 & 0.10 & & 2.36 & 1.28 & \\
\hline LSD for A & & & 0.02 & & & 0.21 & \\
\hline LSD for B & & & 0.01 & & & 0.08 & \\
\hline LSD for $\mathrm{AxB}$ & & & n.s. & & & n.s. & \\
\hline
\end{tabular}


Table 5

Effect of chilling on photosynthetic rate and total leaf area in cucumber plants treated with triacontanol (TRIA) and Asahi SL.

\begin{tabular}{|c|c|c|c|c|c|c|c|}
\hline \multirow[b]{2}{*}{ Biostimulator (A) } & \multirow[b]{2}{*}{ Concentration } & \multicolumn{2}{|c|}{ Growth conditions (B) } & \multirow{2}{*}{$\begin{array}{l}\text { Mean } \\
\text { for A }\end{array}$} & \multicolumn{2}{|c|}{ Growth conditions (B) } & \multirow{2}{*}{$\begin{array}{l}\text { Mean } \\
\text { for A }\end{array}$} \\
\hline & & $\begin{array}{l}\text { without } \\
\text { chilling }\end{array}$ & with chilling & & $\begin{array}{l}\text { without } \\
\text { chilling }\end{array}$ & with chilling & \\
\hline & \multicolumn{4}{|c|}{ photosynthesis $\left(\mu \mathrm{mol} \times \mathrm{m}^{-2} \times \mathrm{s}^{-1}\right)$} & \multicolumn{3}{|c|}{ leaf area $\left(\mathrm{dm}^{2} \times\right.$ plant $\left.^{-1}\right)$} \\
\hline Control & $\mathrm{H}_{2} \mathrm{O}$ & 5.22 & 3.00 & 4.11 & 7.34 & 5.28 & 6.31 \\
\hline \multirow{3}{*}{$\begin{array}{l}\text { TRIA } \\
\left(\mathrm{mg} \times \mathrm{dm}^{-3}\right)\end{array}$} & 0.01 & 6.36 & 4.14 & 5.25 & 7.43 & 5.85 & 6.64 \\
\hline & 0.1 & 6.85 & 4.85 & 5.85 & 7.65 & 5.94 & 6.79 \\
\hline & 1.0 & 6.08 & 3.84 & 4.96 & 8.12 & 6.02 & 7.07 \\
\hline \multirow{2}{*}{$\begin{array}{l}\text { Asahi SL } \\
(\%)\end{array}$} & 0.2 & 6.74 & 4.78 & 5.76 & 8.27 & 6.14 & 7.20 \\
\hline & 0.3 & 7.05 & 4.82 & 5.93 & 9.53 & 6.61 & 8.07 \\
\hline Mean for B & & 6.71 & 4.24 & & 8.06 & 5.97 & \\
\hline LSD for A & & & 0.53 & & & n.s. & \\
\hline LSD for B & & & 0.21 & & & 0.87 & \\
\hline LSD for $\mathrm{AxB}$ & & & n.s. & & & n.s. & \\
\hline
\end{tabular}

Chilling stress inhibited particularly strongly leaf gas exchange processes in cucumber, as the plants treated with a temperature of $12 / 6^{\circ} \mathrm{C}$, compared to those growing at $27 / 22^{\circ} \mathrm{C}$ (day/night), showed on the average nearly twice lower leaf stomatal conductance, which has been also observed by $\mathrm{S}$ t a r c k et al. (2000) in tomato under the influence of chilling stress. Such behaviour of stomata in leaves, for understandable reasons, resulted in a nearly $46 \%$ decline in transpiration and a $37 \%$ decline in photosynthesis (Tab. 4 and 5). The rapid decrease in $\mathrm{CO}_{2}$ assimilation in plant leaves under chilling conditions has also been found by Foyer et al. (1994a), Haldimann (1998), $\mathrm{S}$ ta r ck et al. (2000) and J u a $-\mathrm{S} \mathrm{ung} \mathrm{s} \mathrm{o} \mathrm{o} \mathrm{et} \mathrm{al.}$ (2001). The reduction in the $\mathrm{CO}_{2}$ assimilation rate induced by low temperature stress leads to insufficient supply of natural electron acceptors, in particular NADP; in this situation, $\mathrm{O}_{2}$ becomes such acceptor, which leads to the generation of RFT in cells ( $\mathrm{R} \mathrm{o} \mathrm{b} \mathrm{-}$ in s o n , 1988; Ö qu i s t and H u n e r, 1993). The application of the biostimulators in the pre-stress period clearly mitigated the negative effect of chilling on the gas exchange processes in question. The use of TRIA in the untreated and chilling-treated plants increased the average leaf stomatal conductance by $27.3 \%$ relative to the control treatment, and the application of Asahi SL increased this parameter by as much as $50 \%$. The respective data for transpiration are $10.5 \%$ and $20.4 \%$, whereas for photosynthesis $30.2 \%$ and $42.1 \%$.
The beneficial effect of triacontanol on $\mathrm{CO}_{2}$ assimilation in plants has also been found by $\mathrm{Mis} \mathrm{tra}$ and Srivastava (1991), Muthuchelian et al. (1995), I w a now and Ange low (1997) as well as B la mowski et al. (1998), whereas the same has been found by Gaw roń s k a et al. (2008) as well as Wróbe 1 and W oźniak (2008) with respect to the biostimulator Asahi SL. TRIA mitigated, to the greatest extent, the negative effects of chilling on the gas exchange processes in cucumber leaves at a concentration of $0.1 \mathrm{mg} \times \mathrm{dm}^{-3}$, whereas Asahi SL at a concentration of $0.3 \%$ (Tab. 4 and 5).

As a result of its direct effect on growth processes as well as through the inhibition of $\mathrm{CO}_{2}$ assimilation, chilling stress significantly restricted plant growth. The results contained in Tab. 5 indicate that, irrespective of the earlier application of the biostimulators, the chilling-treated plants developed a $25.9 \%$ smaller total leaf area compared to the plants grown at a temperature of $27 / 22^{\circ} \mathrm{C}$. The pre-chilling application of the biostimulators, in particular Asahi SL, increased the leaf area growth rate; however, it was not confirmed statistically. The beneficial effect of triacontanol on plant growth has also been confirmed by B or ow s ki (1992), whereas in the case of Asahi SL by Djanaguiraman et al. (2005), Górnik and Grzesik (2005) as well as Gawrońska et al. (2008). 


\section{CONCLUSIONS}

1. The three-day period of treatment of young cucumber plants with a temperature of $12 / 6^{\circ} \mathrm{C}$ (day/night) caused a significant increase in electrolyte leakage, free proline content and in the activity of guaiacol peroxidase in leaves, but a decrease in chlorophyll $\mathrm{a}+\mathrm{b}$ content, stomatal conductance, transpiration, photosynthesis, leaf area and in the activity of catalase in leaves.

2. The application of triacontanol or ASAHI SL in leaves in the pre-stress period reduced the value of the parameters which had been increased as a result of chilling and increased those which had decreased. Generally, TRIA was most effective at a concentration of $0.1 \mathrm{mg} \times \mathrm{dm}^{-3}$, and Asahi SL at a concentration of $0.3 \%$.

3. In the light of the results obtained, foliar application of biostimulators (TRIA, Asahi SL) may be an efficient method of mitigating the negative effects of chilling stress in thermophilic plants.

\section{REFERENCES}

Aebi H., 1984. Catalase in vitro. Methods Enzymol. 105: 121-126.

A it-B arka, Audran J. C., 1997. Response of champenoise grapevine to low temperature: changes of shoot and bud proline concentrations in response to low temperatures and correlations with freezing tolerance. J. Hortic. Science, 72: 577-582.

A rnon D. J., 1949. Cooper enzymes in isolated chloroplasts: Polyphenoloxidase in Beta vulgaris. Plant Physiol. 24: 1-15.

Bates L. S., Waldren R. R., Teare I. D., 1973. Rapid determination of free proline for water - stress studies. Plant Soil, 39: 205-207.

Blamowski Z. K., Borowski E., Blamowska M., 1998. Wpływ długołańcuchowych alkoholi alifatycznych na wzrost, wymianę gazową i rozdział asymilatów w roślinach rzodkiewki. / Effect of long chain aliphatic alcohols on growth, gas exchange and assimilate partitioning in radish plants. / Acta Agrobot. 1-2: 5-10.

B orowski E., 1992. Wpływ triakontanolu na wzrost, kwitnienie i owocowanie pomidorów. / The influence of triacontanol (TRIA) on the growth, blooming and fruiting of tomatoes. / Ann. Univ. Mariae Curie-Skłodowska sect. E. 47: 241-249.

B ritt on G., 1985. General carotenoid methods. Methods Enzymol. 111: 113-114.

Chen Y. Y., Lin C., 1993. Effect of LAB 173711, an ABA analogue, on low - temperature resistance of mung bean seedlings. J. Plant Growth Regul. 12: 51-55.

Chen W. P., Li P. H., 2002. Membrane stabilization by abscisic acid under cold aids proline in alleviating chilling injury in maize (Zea mays L.) cultured cells. Plant Cell Environ. 25: 955-962.
De Kok J. L., Kuiper P. J. C., 1977. Glycolipid degradation in leaves of the thermopholic Cucumis sativus as affected by light and low temperature treatment. Physiol. Plant, 39: 123-128.

Djanaguiraman M., Pandiyan M., Durgadevi D., 2005. Abscission of tomato fruit follows oxidative damage and its manipulation by Atonik spray. Int. J. Agr. Biol. 07-1-39-44. http://www.ijab.org.

Dong Hee Lee, Chin Bum Lee, 2000. Chilling stress - induced changes of antioxidant enzymes in the leaves of cucumber: in gel enzyme activity assays. Plant Science, 159: 75-85.

E1-S a ht H. M., 1998. Responses to chilling stress on French bean seedlings: antioxidant compounds. Biologia Plant. 41 (3): 395-402.

Feng-Zhaozhong, Guo Anhong, Feng-Zongwei, 2003. Amelioration of chilling stress by tradimefon in cucumber seedlings. Plant Growth Reg. 39 (3): 277-283.

Foyer C. I., Descourvieres P., Kunert K. I., 1994a. Protection against oxygen radicals: an important defence mechanism studied in transgenic plants. Plant Cell Environ. 17: 507-523.

Gawrońska H., Przybysz A., Słowiński A., 2008. Biologiczne podstawy działania biostymulatora Asahi SL. / Biological basis of the mode of action of the Asahi SL biostimulator/. Materiały konferencji pt. „Biostymulatory w nowoczesnej uprawie roślin”. SGGW W-wa: 20.

Górnik K., Grzesik M., 2005. China aster plant growth, seed yield and quality as influenced by Asahi SL treatment. Folia Hort. 17/2: 119-127.

Górnik K., Grzesik M., Mika A., 2007. Improvement of grapevines rooting and growth of plants under stress conditions by Asahi SL. Folia Hort. 19/2: 57-67.

Graham D., Patters on B. D., 1982. Responses of plants to low non-freezing temperatures: proteins, metabolism and acclimation. Ann. Rev. Plant Physiol. 33: 347-372.

Haldimann P., 1998. Low growth temperature - induced changes to pigment composition and photosynthesis in Zea mays genotypes differing in chilling sensitivity. Plant Cell Environ. 21: 200-208.

Hare P. D., Cress W. A., 1997. Metabolic implications of stress induced proline accumulation in plants. Plant Growth Reg. 21: 79-102.

Iwanow A. G., Angelow M. N., 1997. Photosynthesis response to triacontanol correlates with increased dynamics of mezophyll protoplast and chloroplast membranes. Plant Growth Reg. 21: 145-152.

Jun-Sungsoo, Kim-Jongmin, Lee-Chinbum, 2001. A comparative study on the effect of chilling treatment in the light and in the dark on subsequent photosynthesis in cucumber. Australian J. Plant Physiol. 28 (6): 489-496.

Kang H. M., Saltveit M. E., 2002. Effect of chilling on antioxidant enzymes and DPPH - radical scavenging activity of high - and low - vigour cucumber seedling radicles. Plant Cell Environ. 25: 1233-1238. 
Kumaravelu G., Livingstone D. V., Ramanuja m M. P., 2000. Triacontanol induced changes in the growth, photosynthetic pigments, cell metabolites, flowering and yield of green gram. Biologia Plant. 43 (2): 287-290.

Małolepsza U., Urbanek H., Polit J., 1994. Some biochemical of strawberry plants to infection with $\mathrm{Bo}$ trytis cinerea and salicylic acid treatment. Acta Agrobot. 47: 73-81.

Markowski A., Skrudlik G., 1995. Electrolyte leakage, ATP content in leaves and intensity of net photosynthesis in maize seedlings at permanent or different daily exposure to low temperature. J. Agron. Crop. Sci. 175: 109-117.

Mikos-Bielak M., Michałek W., 1999. Zmiany zawartości barwników asymilacyjnych i aktywności fotosyntetycznej liści ogórka i ziemniaków traktowanych Atonikiem. / Changes in assimilation pigments content and photosynthetic activity of cucumber and potato leaves treated with Atonic/. Materiały konferencji pt. „Hodowla roślin ogrodniczych u progu XXI wieku”. Lublin: 23-25.

Mistra A., Srivastava N. K., 1991. Effect of triacontanol formulation „Miraculan” on photosynthesis, growth, nutrient uptake and essential oil yield of lemongrass (Cumbopoda flexuonses Steud. Watts). Plant Growth Reg.

Muthuchelian K., Murugan C, Harigovindan R., Nedunchezhian N., Kulandaivelu G., 1995. Effect of triacontanol in flooded Erythrina variegata seedlings 1. Changes in growth, photosynthetic pigments and biomass productivity. Photosynthetica, 31: 269-275.

Öquist G., Huner N. P. A., 1993. Cold-hardening induced resistance to photoinhibition of photosynthesis in winter rye is dependent upon an increased capacity for photosynthesis. Planta, 189: 150-156.

Robinson J. M., 1988. Does $\mathrm{O}_{2}$ photoreduction occur in chloroplasts in vitro? Physiol. Plant. 72: 666-780.

Starck Z, Niemyska B., Bogdan J., Akotur Tawalbeh R. N., 2000. Response of tomato plant to chilling stress in associated with nutrient or phosphorus starvation. Plant Soil, 226: 99-106.

Wolfe D. W., 1991. Low temperatures effects on early vegetative growth, leaf gas exchange and water potential of chilling - sensitive and chilling - tolerant crop species. Ann. Bot. 67: 205-212.

Wróbel J., Woźniak A., 2008. Wpływ sposobów stosowania stymulatora wzrostu Atonik na aktywność fizjologiczną i plon wierzby wiciowej (Salix viminalis L.). / The effect of Atonic plant growth stimulator, applied by different methods on the physiological activity and yield of common osier (Salix viminalis L.). Materiały konferencji pt. „Biostymulatory w nowoczesnej uprawie roślin". SGGW W-wa: 86.

\section{Reakcja na chłód roślin ogórka traktowanych triakontanolem i Asahi SL}

\section{Streszczenie}

W doświadczeniach wazonowych prowadzonych na ogórku odm. Śremski $F_{1}$ badano wpływ okresowego chłodu na rośliny wcześniej traktowane triakontanolem (TRIA) i Asahi SL. Rośliny rosły w fitotronie w temp. powietrza $27 / 22^{\circ} \mathrm{C}$ (dzień/noc), korzystając ze światła fluorescencyjnego o gęstości strumienia FAR $220 \mu \mathrm{mol} \times \mathrm{m}^{-2} \times \mathrm{s}^{-1}$, przy fotoperiodzie 16/8. W fazie 4-tego liścia właściwego odpowiednie serie doświadczalne opryskano: 1) $\mathrm{H}_{2} \mathrm{O}$ - kontrola, 2) TRIA $0.01,3)$ TRIA $0.1,4)$ TRIA $1.0 \mathrm{mg} \times \mathrm{dm}^{-3}$, 5) Asahi SL 0.2, 7) Asahi SL 0.3\%. Po 24 godzinach połowę roślin z każdej serii doświadczalnej traktowano przez okres 3 dni temp. $12 / 6^{\circ} \mathrm{C}$ przy niezmienionych pozostałych warunkach wzrostu. Uzyskane wyniki wykazały, że okresowy chłód wywołał istotny wzrost stopnia wypływu elektrolitów, zawartości wolnej proliny i aktywności peroksydazy gwajakolowej w liściach, spadek zaś zawartości chlorofilu ,a+b”, przewodności szparkowej, transpiracji, fotosyntezy, powierzchni liści i aktywności w nich katalazy. Aplikacja na liście w okresie przedstresowym TRIA lub ASAHI SL obniżyła wartość tych cech, które w wyniku chłodu uległy podwyższeniu, a podwyższyła te które uległy obniżeniu. Na ogół najbardziej skuteczny był TRIA w stężeniu $0.1 \mathrm{mg} \times \mathrm{dm}^{-3}$, a Asahi SL w stężeniu $0.3 \%$. 